\title{
REFLEKS FONEM PROTO AUSTRONESIA PADA BAHASA ACEH
}

\author{
oleh Teguh Santoso \\ Balai Bahasa Banda Aceh
}

\begin{abstract}
Aceh language have similarity with Campa language. So, there are two language which have many similarities vocabulary. The theritory of Aceh and Campa is located in the north east of Sumatera island (Vietnamese). There are Austronesian language grouping.

In past, Aceh language have effect from other like Arabic, Netherland, Pourtouguese, Espana, and Chinese.

This article explaining the retention and inovation about Aeh language by reflection of their vocabulary with Austronesia protofonem. Austronesian protofonem is the list of the reconstruction of the individual language: Tagalog, Toba-Batak, Java, Malay, NgajuDayak, and Hova. The analysis showed that Aceh language vocal and consonant have been shift and split in their reflection.
\end{abstract}

Keywords: fonem reflect, proto, inovation, retention

\section{A. Latar Belakang}

Dalam perkembangannya, bahasa dimana pun ia berada selalu dalam keadaan berkembang secara terus-menerus (Crystal, 1992:328). Dengan bertumpu pada kerangka teori linguistik komparatif, yang mempersoalkan bahasa dalam bidang waktu dan perubahan-perubahan unsur bahasa yang terjadi dalam bidang waktu tersebut, penelitian mengenai refleks fonem vokal dan konsonan Proto Austronesia (PAN) pada bahasa Aceh (BA) ini, berusaha memaparkan perubahan-perubahan yang terjadi dari Proto Austronesia pada tataran fonologi dan leksikal. Tataran yang dipergunakan untuk mengadakan perbandingan antarbahasa tersebut adalah bidang fonologi. Pada tataran ini telaah komparatif dapat dilaksanakan secara mandiri tanpa mengacu kepada tataran yang secara hierarki lebih tinggi yaitu bidang morfologi, sintaksis, dan semantis (Lehman, 1973:8; Dyen, 1978:35; Bynon, 1979:25 via Fernandez, 1996:20). 
Dengan demikian, setiap bahasa yang digunakan sebagai alat komunikasi antarsesama penuturnya mempunyai relasi atau hubungan kekerabatan dengan bahasa lainnya, baik jauh maupun dekat. Secara garis besar tugas utama linguistik historis komparatif adalah menetapkan fakta dan tingkat kekerabatan antarbahasa, yang berkaitan erat dengan pengelompokkan bahasa-bahasa kerabat (Antilla dalam Fernandez, 1996:14). Menetapkan fakta kebahasaan berkaitan dengan penentuan atau perumusan kaidah-kaidah perubahan bunyi, apakah bersifat teratur (korespondensi) atau tidak teratur (sporadis).

Hubungan kekerabatan suatu bahasa dapat dibuktikan melalui rekonstruksi unsur-unsur retensi atau kesamaan (pemertahanan) maupun inovasi atau perubahan dari bahasa asalnya (protobahasa), baik pada tataran fonologi, leksikon, maupun gramatikal. Protobahasa adalah suatu gagasan teoritis yang dirancang dengan cara sederhana yang dihubungkan dengan sistem-sistem bahasa sekerabat dengan memanfaatkan sejumlah kaidah (Bynon dalam Masrukhi, 2002:86). Perubahan suatu bahasa dan bahasa-bahasa sekerabat dapat dilacak dengan mengembalikan kepada bentuk protobahasanya, yaitu dengan cara mengamati perubahan pada tahap yang paling awal. Tahap paling awal adalah perubahan bunyi pada tataran fonologisnya.

Bahasa Aceh adalah salah satu bahasa yang termasuk dalam rumpun Austronesia yang sehari-hari masih digunakan oleh suku Aceh. Suku bangsa Aceh merupakan jumlah mayoritas yang terdapat di Provinsi Nanggroe Aceh Darussalam. Sebagian besar masyarakat Aceh merupakan penutur bahasa Aceh.

Berkaitan dengan uraian tersebut di atas, maka persamaan dan perbedaan yang terjadi pada BA dengan bahasa induknya PAN dapat dirunut kembali hubungan kekerabatannya dengan cara merekonstruksi refleks fonem-fonem, yaitu fonem vokal dan konsonan kedua bahasa tersebut.

Pengamatan terhadap BA ini bertujuan menjelaskan retensi dan inovasi yang terjadi pada BA, serta menjelaskan refleks protofonem vokal dan konsonan PAN pada BA. Adapun hal yang diharapkan dari penelitian ini adalah mengetahui kaidah perubahan fonem (bunyi) Proto Austronesia dalam bahasa Aceh.

Refleks Fonem Proto Austronesia pada Bahasa Aceh (Teguh Santoso) 
Dengan demikian, muncullah permasalahan-permasalahan yang dapat diajukan sebagai berikut. Pertama, retensi atau inovasi apakah yang terjadi pada fonem vokal dan fonem konsonan bahasa Aceh?. Kedua, bagaimanakah refleks vokal dan konsonan PAN pada bahasa Aceh?

Bynon (dalam Fernandez, 1981:7) mengatakan bahwa para ahli bahasa Indo Eropa berhasil melakukan pengamatan terhadap perubahan yang terjadi pada bahasa-bahasa yang termasuk dalam rumpun bahasa Indo Eropa. Mereka berusaha merekonstruksi bahasa proto Indo Eropa sebagai suatu konstruksi yang ada. Konstruksi hipotesis semacam itu, baik bentuk maupun urutan katanya, dapat mempresentasikan sejarah sistem fonem dari bahasa-bahasa berkerabat dalam kurun waktu yang nyata.

Titik awal diterimanya asumsi itu adalah korespondensi antarbahasa berkerabat dalam rumpun bahasa Indo Eropa. Selain itu, dapat diamati pula kaidah-kaidah yang memperlihatkan hubungan gramatikal pada bahasa-bahasa yang bersangkutan. Dalam studinya mengenai bahasa Indo German, Jacob Grimm (dalam Fernandez, 1981) mengamati korespondensi sistematis sejumlah fonem konsonan dari bahasa-bahasa yang tergolong dalam subkelompok itu. Ia melihat adanya hubungan yang tetap antarfonem konsonan pada bahasa-bahasa itu sehingga dapat diasumsikan bahwa unsur-unsur kebahasaan yang merupakan peninggalan dari bahasa purba sampai sekarang secara bersama masih tersimpan dalam kosakata bahasa-bahasa sekerabat.

Menurut Bynon, apa yang dicapai oleh studi perbandingan bahasa Indo Eropa di bidang fonologi itu merupakan dasar asumsi yang mapan, yang diterima secara umum di kalangan para ahli perbandingan bahasa, bahwa tolok ukur utama penentuan kekerabatan antarbahasa lazimnya ditentukan oleh komponen fonologis. Tataran jenis ini, oleh kaum Neogramarian dipandang sebagai tataran yang secara otonomi terpisah dari tataran gramatikal, yang berarti kaidah-kaidah fonologis itu dibentuk tanpa merujuk pada referensi tataran morfologi, sintaksis, atau semantik (Fernandez, 1981:25).

Kaum Neogramarian berpendapat bahwa perubahan bahasa yang terjadi pada tataran fonologis diakibatkan oleh adanya keteraturan perubahan bunyi yang cenderung bersifat fonetis. Dalam proses

DIKSI Vol.12, No.2, Juli 2005 
pengamatan itu, kata mempunyai peranan yang penting karena hanya dalam kata itulah perubahan fonem itu tertampakkan.

Bynon (dalam Fernandez, 1981:20) mengatakan bahwa pada dasarnya, semua bahasa mengalami perubahan, terutama yang terjadi pada bahasa-bahasa sekerabat, pada umumnya selalu memperlihatkan bentuk-bentuk yang mendekati bentuk asalnya. Kalaupun ada perbedaan, menurutnya hal itu hanya tampak pada permukaannya saja, karena jika sudah ditemukan hukum bunyi, perbedaan-perbedaan itu sudah bukan masalah lagi. Perbedaan itu terjadi semata-mata disebabkan oleh berlakunya hukum perubahan bunyi secara umum.

Bynon (dalam Fernandez, 1981:11) lebih lanjut mengatakan bahwa apa yang dikemukakan di atas, sebenarnya berpijak pada asumsi diterimanya sistem proto pada kekerabatan antarbahasa dengan merujuk pada adanya kemiripan yang dimiliki oleh anggota bahasa sekerabat. Kaum Neogramarian menegaskan bahwa bahasa proto tidak lain dari suatu konstruksi teoretis yang dirancang secara sangat ekonomis untuk menghubungkan sistem bahasa-bahasa sekerabat dengan memanfaatkan kaidah-kaidah yang ada. Konsep tersebut memberikan ikhtisar pengetahuan pada masa sekarang tentang adanya hubungan sistematis bahasa-bahasa yang berkerbat.

Menurut Jeffer dan Lehiste (dalam Ibrahim dan Samsudin, 1982:13) salah satu kajian mengenai bahasa adalah kajian perubahan bunyi. Kajian perubahan bunyi-bunyi bahasa serta jenis-jenisnya merupakan kajian yang telah lama berkembang dalam studi tentang perubahan bahasa (linguistik diakronis). Istilah perubahan bahasa dipakai untuk memberi arti bahwa dalam pengertian luas, perubahan-perubahan bentuk baik segmental maupun suprasegmental diakibatkan oleh proses fonologi. Istilah perubahan bunyi ini banyak dipakai dalam linguistik komparatif.

Kerangka dasar penelitian ini berpijak pada teori linguistik historis komparatif dengan menitikberatkan pada tataran fonologis. Sejauh ini, banyak ahli bahasa yang telah memberikan definisi mengenai fonologi. Fonologi bidang khusus dalam linguistik yang mengamati bunyi-bunyi 
suatu bahasa tertentu menurut fungsinya untuk membedakan makna leksikal dalam bahasa tersebut (Verhaar, 1988: 36). Pendapat ini diperkuat oleh Hyman (1978:2) yang mengatakan bahwa fonologi adalah studi tentang sistem bunyi, atau dapat juga disebut sebagai studi mengenai bagaimana struktur bunyi ujaran dan fungsinya dalam suatu bahasa.

Dalam hubungannya dengan kajian linguistik komparatif, Crowley (1992:38-57) menyebutkan tipe-tipe perubahan bunyi sporadis, yaitu lenition (pelemahan bunyi), sound addition (penambahan bunyi), metathesis (metatesis), fusion (penggabungan), dan assimilation (asimilasi). Selain itu, kaidah perubahan bunyi menurut Antilla (1989:6870) berupa split (pembelahan), merger (paduan), zero (pelesapan).

Tentang istilah retensi, Greenberg mengatakan bahwa retensi adalah unsur warisan dari bahasa asal yang tidak mengalami perubahan pada bahasa sekarang. Dalam perkembangan historis, bahasa sekerabat secara eksklusif pada umumnya melalui suatu masa (periode) perkembangan yang sama. Akan tetapi, inovasi bersama yang dialami bahasa sekerabat secara eksklusif pada umumnya melalui suatu masa perkembangan bersama.

\section{B. Fonologi Bahasa Aceh}

Sistem fonologi bahasa Aceh yang dikemukakan Sawyer dalam disertasinya berjudul Achinese Historical Phonology (1939:9) hanya menyebutkan fonem vokal dan fonem konsonan saja. Sawyer menyebutkan sistem fonem vokal terdiri atas delapan fonem, sedangkan fonem konsonan berjumlah sembilan belas fonem. Sawyer tidak melakukan pembagian secara terinci terhadap masing-masing vokal maupun konsonan. Fonem vokal bahasa Aceh terdiri atas /i/, /u/, /e/, /d/, /o/, /é/, /a/, / /. Fonem konsonan yang digunakan Sawyer bagi studi ini bersifat segmental, terdiri atas fonem /p/,/t/, /c/, /k/, /?/, /b/, /d/, /j/, /g/, /s/, /h/, /m/, /n/, / /n/, /y/, /w/, /y/, /1/, /r/. Di samping fonem vokal dan konsonan tersebut, Sawyer hanya menyebutkan adanya gugus konsonan nasal. Akan tetapi, gugus konsonan nasal tersebut tidak dibahas secara mendalam.

DIKSI Vol.12, No.2, Juli 2005 
Vokal dan konsonan dalam bahasa Aceh, memiliki distribusi sebagai berikut.

\section{Distribusi Fonem Vokal}

\begin{tabular}{|c|c|c|c|}
\hline Fonem & Awal & Tengah & Akhir \\
\hline$/ a /$ & adeuen'abang' & rab'dekat' & raga 'bakul' \\
\hline$/ \partial /$ & Jntat 'antar' & andk'anak' & 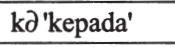 \\
\hline /i/ & iku 'ekor' & bit 'benar' & meuri 'jelas' \\
\hline lél & lé 'banyak' & beuhék 'bagian' & beuhé 'berani' \\
\hline le/ & eh 'tidur' & hek'lelah' & le 'lelah' \\
\hline $10 /$ & ok-ok 'bunyi' & boh 'buah' & po'punya' \\
\hline וכו & - & bつy 'buang' & deuno 'dengar' \\
\hline$/ \mathrm{u} /$ & u 'kelapa' & turi 'kenal' & karu 'ribut' \\
\hline
\end{tabular}

\section{Distribusi Fonem Konsonan}

\begin{tabular}{|c|c|c|c|}
\hline Fonem & Awal & Tengah & Akhir \\
\hline$/ \mathrm{b} /$ & ba 'bawa & keubah 'simpan' & asab 'asap' \\
\hline$/ \mathrm{p} /$ & pat 'dimana' & tapeh 'sabut' & $\cdots$ \\
\hline$/ \mathrm{m} /$ & mat'pegang' & kamoe 'kami' & som 'sembunyi' \\
\hline$/ \mathrm{t} /$ & toe 'dekat' & atra 'harta' & ariet 'potong' \\
\hline$/ d /$ & dit 'sedikit' & adoe 'adik' & - \\
\hline$/ \mathrm{n} /$ & na'ada' & seuneuna 'semua' & nan 'nama' \\
\hline$/ \mathrm{k} /$ & ka 'sudah' & akai 'akal' & adak'andai' \\
\hline$/ \eta /$ & Dui 'pakai' & mayat 'enak' & kh'ien 'bau' \\
\hline$/ \mathrm{c} /$ & cue 'curi' & licen 'licin' & -- \\
\hline$/ \tilde{\mathrm{n}} /$ & ñoe 'ini & pañot 'lampu' & -- \\
\hline /1/ & li 'hapus' & mala 'layu' & - \\
\hline$/ \mathbf{r} /$ & ro 'tumpah' & arat 'sempit' & -- \\
\hline$/ \mathrm{s} /$ & si 'arah' & asoe 'daging' & - \\
\hline$/ \mathrm{y} /$ & yue 'suruh' & ayeuem 'mainan' & -- \\
\hline$/ \mathrm{h} /$ & han 'tidak' & neiheun 'tambak' & boh 'buah' \\
\hline$/ j /$ & jan 'waktu' & sijuek 'dingin' & -- \\
\hline /w/ & woe 'pulang' & saweue 'kunjung' & -- \\
\hline /g/ & Gampon'kampung' & lagee'seperti' & -- \\
\hline$/ ? /$ & -- & - & aneu?'anak' \\
\hline
\end{tabular}




\section{Sistem Fonem Proto Austronesia}

Dempwolf dalam bukunya yang berjudul Deduktive Anwendung des Urindonesischen auf Austronesische Einzelsprachen (1937) telah berhasil merekonstruksi fonem Proto Austronesia, dengan berdasarkan sejumlah bahasa Austronesia seperti Jawa, Batak, Malagasi, dan Melayu. Adapun rekonstruksi fonem Proto Austronesia tersebut dapat dilihat pada bagan di bawah ini.

Distribusi fonem-fonem vokal PAN sebagai berikut.

$*_{\text {i-: }}$ ijuSun 'hidung';

*-i: *qubi 'ubi'

*u-: *ulaR 'ular'; *-u-: *manuk 'burung', *-u: *bulu 'bulu’

*a-: *alas 'hutan ${ }^{\mathrm{t}}$; *a-: *Zalan 'jalan'; *-a: *mata 'mata'

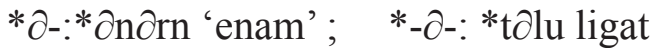

Konsonan-konsonan /p/, /b/, /D/, /c/, /t/, /d/, /s/, /k/, /g/, /m/, /n/, /y/, /r/, /R/, /1/, /S/, /h/, /q/ memiliki distribusi lengkap. Di sisi lain, konsonan-konsonan yang hanya berdistribusi awal dan tengah adalah /z/, /Z/, /ñ/, /T/, /w/, dan /y/; sedangkan fonem /j/ hanya terdapat pada posisi tengah dan akhir kata.

\section{Refleks Fonem}

Penemuan kaidah perubahan bunyi (fonem) bahasa proto dalam bahasa-bahasa yang dilahirkannya merupakan salah satu hasil yang diperoleh dan kegiatan ilmu perbandingan bahasa seperti tujuan yang diharapkan dan penelitian Refleks Fonem Proto Austronesia dalam Bahasa Aceh ini. Sejauh mana kaidah perubahan fonem itu dihasilkan penganalisisannya dapat kita lihat seperti berikut.

\section{Refleks Fonem Vokal}

1) $* \mathrm{a}$

$$
\begin{aligned}
& \text { *anak }>\underline{a n} \underline{\partial} \text { 'anak' } \\
& \text { *Rumaq }>\text { rumoh 'rumah' } \\
& \text { *ma-nawa }>\text { m } \underline{\partial} \text { n } \underline{\text { aw }} \partial \mathbf{y} \text { 'bernyawa' }
\end{aligned}
$$

Pada umumnya data yang ditemukan dalam proto fonem vokal /a/ mengalami retensi (pemertahanan) yang terjadi pada posisi ultima 
maupun penultima. Hanya sedikit data yang menujukkan terjadinya inovasi, seperti $* / a />\partial$, pada posisi ultima yang berakhir dengan nasal. 2) $*_{\mathrm{i}}$

$$
\begin{aligned}
& { }^{*} \text { kulit }>\text { kulet ' }{ }^{k u l i t}{ }^{\circ} \\
& \text { *boli > blow 'beli' } \\
& \text { *langit > lanet 'langit' } \\
& \text { * qaSira > sira 'garam' }
\end{aligned}
$$

Hal yang sama terjadi pada proto fonem vokal/i/. Gejala yang terjadi bahwa */i/ mengalami retensi yang dapat diperhatikan pada data tersebut di atas. Retensi tersebut terjadi pada hampir semua posisi. Terjadinya inovasi $* / \mathrm{i} />$ /e/ pada posisi ultima apabila berakhir dengan fonem vokal /q/ dan /t/. Sedangkan $* / \mathrm{i} />$ /o/ data yang ditemukan juga sangat terbatas dan hal tersebut terjadi pada posisi ultima yang berakhir dengan $/ \mathrm{i} /$.

3) $* \partial$

$$
\begin{aligned}
& * \mathrm{~d} \partial \mathrm{y} \partial \mathrm{R}>\mathrm{d} \partial \mathrm{y} \partial \text { 'mendengar' } \\
& \text { *bali > blow 'beli' }
\end{aligned}
$$

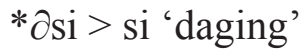

$$
\begin{aligned}
& \text { *monak > min } \partial \mathrm{k} \text { 'minyak' }
\end{aligned}
$$



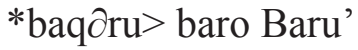

$$
\begin{aligned}
& \text { *Dalom > dalam 'dalam' }
\end{aligned}
$$

Selain retensi pada proto fonem / $/$ / juga terjadi proses inovasi. Retensi yang ditemukan pada umumnya pada $* / \partial /$ pada posisi ultima. Inovasi $* / \partial />$ a terjadi pada posisi ultima yang berakhir dengan fonem nasal. Sedangkan $* / \partial />\varnothing$ terjadi pada posisi penultima yang berada setelah fonem getar (trills) dan pada posisi awal kata. Data yang menunjukkan inivasi $* / \partial />/$ i/ pada posisi penultima merupakan gejala metatesis seperti halnya pada $*$ dilaq $>$ lidah.

4) $* u$

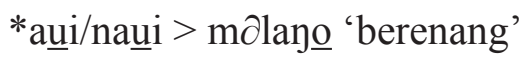

Refleks Fonem Proto Austronesia pada Bahasa Aceh (Teguh Santoso) 


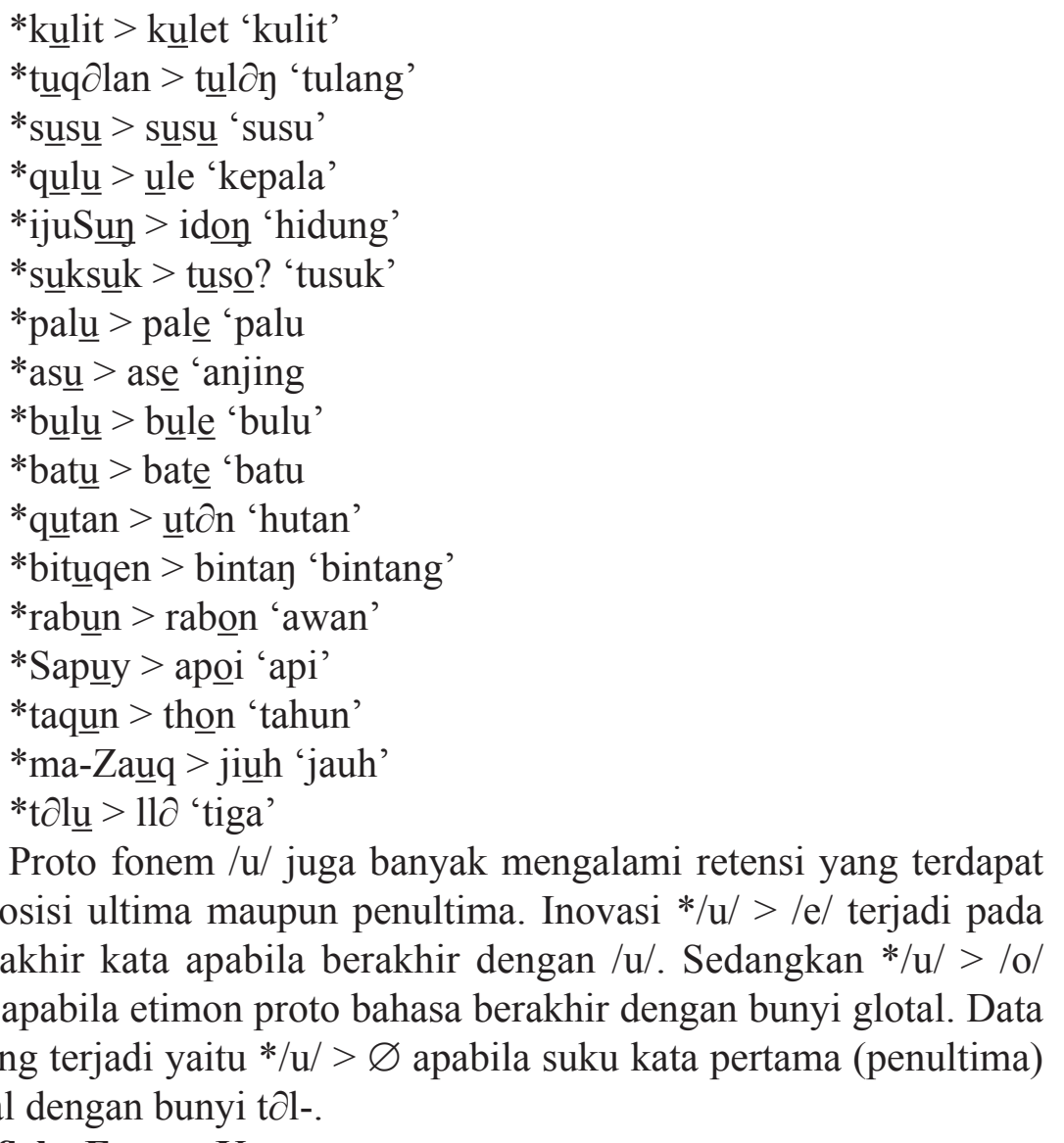

\section{Refleks Fonem Konsonan}

1) $* p$

a) pada posisi penultima (suku kata pertama)

*puteq $>$ puteh 'putih'

*piliq $>$ pileh 'pilih'

$* p>m$ dan $b$, sangat sedikit data yang dapat ditemukan sehingga digolongkan dalam perkecualian. Data tersebut terdapat pada kata berikut.

$$
\begin{aligned}
& \text { *pindah }>\text { minah 'pindah' } \\
& { }^{*} \text { pdzah }>\text { bicah 'pecah' }
\end{aligned}
$$


b) pada posisi ultima (suku kata kedua)

*Sapuy > apoy 'api'

*ma-nipis > tipeh 'tipis'

c) pada posisi akhir kata

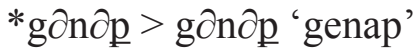

*hirup > hirop 'hirup'

Dengan demikian, berdasarkan pada temuan data di atas *p>p dalam bahasa Aceh pada semua posisi. Hal ini berarti *p mengalami retensi.

2) $* b$

a) pada posisi awal

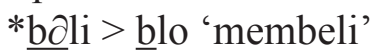

* $\underline{\text { buka }}>$ buka 'buka'

*b $>\mathrm{p}$, data yang ditemukan sangat terbatas hanya pada kata-kata berikut.

*bolaq > plah 'membelah'

* $\underline{b \partial}$ lay > play 'belang'

a) pada posisi ultima

*kabut > kabut 'kabut'

*qabu $>$ abe 'abu'

Pada posisi akhir kata, ${ }^{*} \mathrm{~b}>\mathrm{p}$. Akan tetapi, data yang ditemukan sangat terbatas hanya pada kata *uvab > wap 'uap'.

3) $* t$

a) pada posisi awal.

*tuqdlan > tuley 'tulang'

*talih $>$ talo 'tali'

$* t>l h$, apabila suku penultima berawalan *tol-, misalnya pada data berikut.

*tolu $>$ lhe 'tiga'

$*(\underline{t})$ aluk $>\underline{\text { hor }}$ ' 'teluk'

b) pada posisi tengah

*mata >mata 'mata'

*matey > mate 'mati'

c) pada posisi akhir

*kulit > kulet 'kulit'

Refleks Fonem Proto Austronesia pada Bahasa Aceh (Teguh Santoso) 


$$
\text { *buat }>\text { budt 'buat' }
$$

Berdasarkan data di atas, maka proto fonem $/ \mathrm{t} / \mathrm{mengalami}$ inovasi walupun data pendukung bagi inovasi tersebut sangat terbatas. Inovasi $* / \mathrm{t} />/ \mathrm{lh} /$ apabila suku kata pertama berawal dengan bunyi $* \mathrm{t} \partial \mathrm{l}$ 4) $* d$

a) pada posisi awal

$$
\begin{aligned}
& *(\underline{\mathrm{d}}) \text { ardq }>\text { darah 'darah' } \\
& *(\underline{\mathrm{d}}) \text { anaw }>\text { dano 'danau' }
\end{aligned}
$$

b) pada posisi tengah

*d'adi > jadeh 'jadi/menjadi'

*tudun > tudon 'tutup kepala/tudung'

c) pada posisi akhir

$$
\begin{aligned}
& \text { *hanu} \underline{d}>\text { hañot 'hanyut' } \\
& \text { *bukid }>\text { buket 'bukit' }
\end{aligned}
$$

Proto fonem /d/ juga mengalami inovasi. Hal ini apabila kita mengamati pada data tersebut di atas. Inovasi yang dapat ditemukan berupa pembelahan $* / \mathrm{d} />\varnothing$ pada posisi ultima apabila didahului oleh fonem In/. Kemudian perubahan */d/ > /t/ terjadi pada posisi akhir kata.

5) *D hanya berdistribusi pada posisi awal dan tengah

a) pada posisi awal

* Dusa $>$ Dua 'dua'

* Dalom > Dalam 'di dalam'

b) pada posisi tengah

*ma-nuDip > unep 'hidup'

*Dukㅁk $>$ Duo? 'duduk'

6) $* \mathrm{~s}$

a) pada posisi awal

$$
\begin{aligned}
& \text { * } \underline{\text { susu }}>\text { susu 'susu' }
\end{aligned}
$$

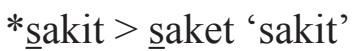

$$
\begin{aligned}
& *_{\mathrm{s}}>\mathrm{h} \text {, hanya terdapat pada data berikut. } \\
& \text { * } \underline{\mathrm{s} \partial \mathrm{la}}>\mathrm{lh} \partial \mathrm{n} \text { 'interval/ jarak' }
\end{aligned}
$$

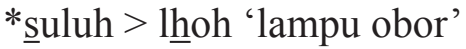


b) pada posisi tengah

$$
\begin{aligned}
& \text { *susu > susu 'susu' } \\
& \text { *asu > ase 'anjing' }
\end{aligned}
$$

c) pada posisi akhir

*ma-nipis > tipeh 'menipis'

*m $\partial \mathrm{sm} \partial \underline{\mathrm{s}}>\mathrm{m} \partial \mathrm{ramah}$ 'meremas'

Berdasarkan data di atas dapat disimpulkan bahwa proto fonem /s/ mengalami proses inovasi yaitu berupa pembelahan. Pembelahan tersebut dapat ditemukan pada $* / \mathrm{s} />/ \mathrm{lh} /$ pada posisi awal kata apabila diikuti oleh fonem vokal / $/$ / dan /u/. Kemudian fonem proto /s/ menjadi /h/ terjadi pada posisi akhir kata.

7) $* \mathrm{c}$

a) pada posisi awal

*cijum > com 'mencium'

* cabay > cabon 'cabang'

Data mengenai etimon yang menggunakan proto fonem /c/ sangat sedikit ditemukan. Oleh karena itu, proto fonem /c/ tidak ditemukan adanya inovasi.

8) $* \mathrm{j}$

a) pada posisi awal tidak ditemukan, pada posisi tengah;

*b(uh)aja > buya 'buaya'

*lajar > layd 'layar'

*cijum > com 'mencium'

b) pada posisi akhir

*tajtaj > titi 'jembatan'

*pakai > pakayan 'pakaian'

Proto fonem $/ \mathrm{j}$ / sangat sedikit data yang ditemukan. Berdasarkan data tersebut, proto fonem $/ \mathrm{j} /$ mengalami inovasi. Inovasi tersebut yaitu $* / \mathrm{j} />/ \mathrm{y} /$ yang terjadi pada posisi ultima apabila berada di antara fonem vokal. Kemudian proto fonem $/ \mathrm{j} />\varnothing$ terjadi apabila berada pada posisi akhir kata. Keterbatasan data etimon proto fonem /j/ disebabkan oleh sedikitnya kosa kata bahasa-bahasa Austronesia yang cenderung menggunakan bunyi-bunyi semi-vokal frikatif.

Refleks Fonem Proto Austronesia pada Bahasa Aceh (Teguh Santoso) 
9) $* Z$

a) pada posisi awal

* Zalan $>$ jalan jalani

* Zarum $>$ jarom 'jarum'

a) pada posisi tengah

*taZzam > tajam 'tajam'

* quZZan > ujon 'hujan'

$* \mathrm{Z}>\mathrm{d}$, hanya ditemui pada data *luZaq $>$ ludoh 'meludah'.

Berdasarkan data di atas, proto fonem /Z/ mengalami inovasi */Z/ $>/ \mathrm{j} /$. Inovasi tersebut terjadi pada semua posisi. Mengenai proto fonem /Z/ dengan proto fonem /j/ berbeda dalam hal tinggi rendahnya bunyi. Hanya saja proto fonem /Z/ cenderung merupakan bunyi frikatif.

10) $* \mathrm{k}$

a) pada posisi awal

* kavad > kawat 'kawat'

* kulit $>$ kulet 'kulit'

b) pada posisi tengah

*katkat $>$ kap 'menggigit'

*ikuR $>$ iko 'ekor'

c) pada posisi akhir

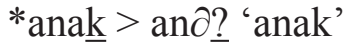



Proto fonem $/ \mathrm{k} /$ juga mengalami inovasi berupa split (pembelahan) yang terjadi pada posisi akhir kata. Inovasi tersebut yakni $* / k />/$ ? Protofonem /k/ walupun merupakan bunyi glotal seperti halnya akan tetapi keduanya berbeda daerah artikulasinya.

11)*g

a) pada posisi awal

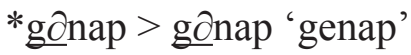

* gigi > gigo 'gigi'

b) pada posisi tengah

* gigi > gigo 'gigi'

*lugi > rugo 'rugi'

DIKSI Vol.12, No.2, Juli 2005 
Data proto fonem /g/ seperti pada di atas hanya di temukan pada posisi awal kata dan pada posisi ultima. Kedua posisi tersebut tidak mengalami inovasi.

12) $* m$

a) pada posisi awal

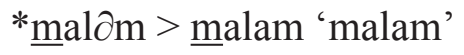

* $\underline{\text { m-utaq }}>$ muntah 'muntah'

b) pada posisi tengah

*mamaq > mamzah 'mengunyah'

*mosm $\underline{\mathrm{m} s}>\mathrm{m} \partial \mathrm{ramah}$ 'meremas'

c) pada posisi akhir

*Zarum $>$ jarom 'jarum'

*taZdom $>$ tajam 'taj am'

Proto fonem $/ \mathrm{m} /$ tidak mengalami inovasi apapun dalam berbagai posisi, baik awal kata, penultima, ultima, maupun akhir kata. Dengan demikian, */m/ mengalami retensi (pemertahanan)

13) $*_{n}$

a) Pada posisi awal data yang ditemukan sangat jarang.

*nipah $>$ lipah 'nipah'

*nipis > lipeh 'tipis'

b) pada posisi tengah

*ka-wanan $>$ undn 'kanan'

*anak > and? 'anak'

c) pada posisi akhir

*Dasun $>$ dun 'daun'

*qutan $>$ ut $\partial \underline{\mathrm{n}}$ 'hutan'

Walupun data yang dapat ditemukan dalam proto fonem /n/ sangat terbatas, terutama pada posisi awal kata, akan tetapi dapat kita temukan adanya inovasi. Inovasi tersebut terjadi pada posisi awal kata, $* / \mathrm{n} />/ 1 /$.

14) $* y$

*y hanya ditemukan satu data pada posisi tengah yaitu * Raya $>$ ray? 'raya'.

Refleks Fonem Proto Austronesia pada Bahasa Aceh (Teguh Santoso) 
a) pada posisi akhir

*qaqay > gaki/ aki 'kaki'

*qatey $>$ ate 'hati'

Etimon proto fonem /y/ sangat jarang ditemukan bahkan pada posisi awal kata tidak ditemukan sama sekali. Namun demikian, proto fonem $/ \mathrm{y} /$ mengalami pelesapan pada posisi akhir kata, $* / \mathrm{y} />\varnothing$.

15) $* \mathrm{r},{ }^{*} \mathrm{R}$

a) pada posisi awal

* $\underline{\mathrm{r} \partial \mathrm{b}} \mathrm{bh}>\underline{\mathrm{r} \partial \mathrm{b}} \mathrm{bh}$ 'rebah'

*ratus $>$ ratoih 'ratus'

b) pada posisi tengah

* garus $>$ garu? 'garuk'

*buruk > brok 'buruk'

c) pada posisi akhir

*ikuR > iku 'ekor'

*bibi $>$ > bibe 'bibir'

Berdasarkan data di atas, protofonem maupun /R/ mengalami inovasi berupa pembelahan. Pada posisi aal dan posisi penultima, proto fonem $/ \mathrm{r} /$ dan $/ \mathrm{R} /$ mengalami pemertahanan. Sedangkan pada posisi akhir kata, $* / \mathrm{r}$ / maupun $* / \mathrm{R} /$ mengalami pelesapan (zero).

16) $* 1$

a) pada posisi awal

*luZaq > ludoh 'ludah'

*lanit $>$ lanet 'langit'

b) pada posisi tengah

*kulit > kulet 'kulit'

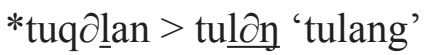

c) pada posisi akhir

*bakal > bakay 'bakal'

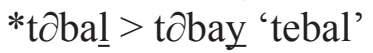

Protofonem /1/ berdasarkan data di atas, mengalami proses berupa pembelahan. Hal ini dapat dilihat pada proto fonem /1/ pada posisi akhir kata. */1/ pada posisi akhir kata dalam bahasa Aceh menjadi 
/y/. Sedangkan pada posisi awal kata, ultima, maupun penultima tidak mengalami perubahan bunyi.

17) *h

a) pada posisi awal

*hirup $>$ hirop 'hirup'

*ha $\mathrm{a}(\mathrm{n}) \mathrm{d} \partial \mathrm{p}>$ ? adap 'hadap'

b) pada posisi tengah

*hikhik > hihi 'tertawa keras'

*ruhan > roun 'ruang'

c) pada posisi akhir

*bantah $>$ bantah 'bantah'

*aduh $>$ adoh 'aduh'

*ta(y)gih $>$ tagi 'kuat/ tangguh'

Proto fonem / $\mathrm{h} /$ juga mengalami inovasi apabila kita lihat data tersebut di atas. Inovasi berupa pembelahan terjadi pada posisi awal kata dan posisi penultima. Pada posisi penultima tersebut $* / \mathrm{h} />\varnothing$ apabila berada di antara dua fonem vokal. Sedangkan $* / \mathrm{h} />\varnothing$ pada posisi awal kata merupakan kaidah primer yang terdapat pada sebagian besar bahasa Austronesia.

18) *q

a) pada posisi awal

*qaqay > aki/ gaki 'kaki'

*qasira $>$ sira 'garam'

b) pada posisi tengah

*tuqdalan > tuloy 'tulang'

*bituq $\partial \mathrm{n}>$ bintay

c) pada posisi akhir

*(d)ardq > darah 'darah'

*basaq > basah 'basah'

Berdasarkan data tersebut di atas, proto fonem /q/ mengalami proses inovasi. Inovasi tersebut yaitu pembelahan berupa lesapnya */q/ pada posisi awal kata dan posisi ultima. Pada posisi awal $* / q />\varnothing$. Sedangkan pada posisi penultima, $* / q />\varnothing$. Hal ini terjadi apabila $* / q /$

Refleks Fonem Proto Austronesia pada Bahasa Aceh (Teguh Santoso) 
berada di antara dua fonem vokal. Inovasi selanjutnya berupa perubahan $* / \mathrm{q} />/ \mathrm{h} /$ yang terjadi pada posisi akhir kata.

19) $* \tilde{n}$

a) pada posisi awal

*namuk $>$ namo? 'nyamuk'

*nala $>$ nala 'nyala'

a) pada posisi tengah

*menak > mina $\underline{\partial}$ ? 'minyak'

*buni $>$ bund 'bunyi/ suara'

Data di atas menunjukkan adanya pemertahanan proto fonem pada posisi awal kata dan pada posisi penultima. Mengenai data *Al/ pada posisi akhir kata tidak ditemui.

20)*

Pada posisi awal, * hanya ditemukan pada data * yilu $>$ yilu 'ngilu'

a) pada posisi tengah

*lanit > lanet 'langit'

*d $\partial \mathrm{y} \partial \mathrm{R}>\mathrm{d} \partial \mathrm{yo}$ 'mendengar'

Etimon proto fonem /y/relatif terbatas yang dapat ditemukan pada data. Namun demikian, tidak terjadi proses inovasi pada proto fonem $/ \mathrm{y} /$.

\section{E. Simpulan}

Berdasarkan analisis refleks fonem-fonem vokal dan konsonan Proto Austronesia pada bahasa Aceh yang telah disajikan di atas, maka dapat dipersingkat berbagai wujud inovasi yang terjadi di dalamnya sebagai berikut.

a. Shift (pergeseran), yaitu perubahan fonem bertipe bunyi tertentu menjadi fonem dengan tipe bunyi lain, dan perubahan tersebut tidak mengubah jumlah fonem bunyi tersebut terdapat pada $/ * \mathrm{q} />/ \mathrm{h} /$, terdapat pada posisi akhir kata dan proto $/ * \mathrm{Z} />/ \mathrm{j} /$

b. Retensi (pemertahanan) yaitu fonem-fonem proto yang tidak mengalami perubahan atau inovasi pada semua posisi kata. Refleks fonem konsonan dalam bahasa Aceh yang tidak mengalami perubahan

DIKSI Vol.12, No.2, Juli 2005 
yaitu $/ * \mathrm{p} /, / *_{\mathrm{b}} /, / *_{\mathrm{di}}, / *_{\mathrm{c}} /, / *_{\mathrm{g}} /, / * \mathrm{~m} /, / *_{\mathrm{h}} /, / *_{\mathrm{n}} /, / *_{\mathrm{y}} /$

c. Split (pembelahan) yaitu proses perubahan fonem proto menjadi dua, zero, atau lebih fonem baru yang berbeda dengan salah satu fonem baru masih mempertahankan fonem proto. Refleks konsonan yang mengalami split tidak keseluruhan sedangkan fonem vokal seluruhnya terjadi pembelahan yaitu $/ *$ a/ menjadi $/ \mathrm{a} /, / \mathrm{o} /, / \mathrm{i} /, / \partial /, / \varnothing /$. Proto /i/ menjadi /i/, /e/, /o/. Proto / $/$ / menjadi / //, /a/, /i/, / $\varnothing /$. Proto /u/ menjadi /u/, /o/, /e/, / $\varnothing /$. Proto $/ \mathrm{t} /$ menjadi /t/ dan $/ \mathrm{h} /$. Proto $/ \mathrm{d} /$ menjadi /d/, / $\varnothing /, / \mathrm{t} /$. Proto $/ \mathrm{s} /$ menjadi /s/, /h/, / $\varnothing /$. Proto $/ \mathrm{j} /$ menjadi $/ \mathrm{j} /, / \varnothing /$. Proto $/ \mathrm{k} /$ menjadi $/ \mathrm{k} /$ dan $/$ ? /. Proto $/ \mathrm{n} /$ menjadi $/ \mathrm{n} /$ dan $/ 1 /$. Proto /r/menjadi /r/ dan / $\varnothing /$. Proto /1/ menjadi /1/ dan /y/. Proto /q/ menjadi $/ \varnothing /$ dan $/ \mathrm{h} /$.

\section{DAFTAR PUSTAKA}

Anceaux, J.A. 1994. Pijar-Pijar Karya Anceaux. Jakarta: PT Djambatan. Antilla, Raimo. 1989. An Introduction To Historical Linguistics. New York: The Mac Milian Company.

Biro Pusat Statistik. 2002. Hasil Sensus Penduduk Sementara 2002. Jakarta: BPS.

Bloomfield, Leonard. 1995. Language (terjemahan). Jakarta: PT Gramedia Pustaka Utama.

Blust, Robert. A. 1981. Historical Linguistics in Indonesia. Part I.

Crystal, David. 1992. The Encyclopedia of Linguistics. Cambridge: Cambridge University Press.

Crowley, Terry. 1992. An Introduction to Historical Linguistics. Oxford: Oxford University Press .

Dyen, Isidore. 1971. The Austronesian Languages and Proto Austronesian in Current Trends in Linguistics. Edited by Thomas A. Sebeok, Vol.8. The Hague: Mouton.

Fernandez, Inyo Yos. 1996. Relasi Historis Kekerabatan Bahasa Flores. Ende: Nusa Indah.

Refleks Fonem Proto Austronesia pada Bahasa Aceh (Teguh Santoso) 
. 2000. Bahan-bahan Kuliah Linguistik Historis Komparatif. S2 Linguistik, Universitas Gadjah Mada, Yogyakarta.

. 1981. Bahasa-bahasa Daerah di Indonesia, Peranan dan

Pengaruhnya terhadap Bahasa Indonesia. Makalah tidak terbit.

Foley, WA. Sumatra Compiled. by W.A. Foley

Hyman, Larry M. 1975. Phonology. New York: Holt.

Jeffers, R. dan Lehiste, I (terjemahan. Ibrahim dan Syamsudin). 1982.

Prinsip dan Metode Linguistik Historis. Surabaya: Usaha Nasional.

Keraf, Gorys. 1984. Linguistik Historis Komparatil Jakarta: Gramedia. Kridalaksana, Harimurti. 1982. Kamus Linguistik. Jakarta: Gramedia.

Mahsun. 1995. Dialektologi Diakronis. Yogyakarta: Gadjah Mada University Press.

Masrukhi, Mohamad. 2002. Refleksi Fonologis Protobahasa Austronesia (PAN) pada Bahasa Lubu dalam Jurnal Fakultas Ilmu Budaya UGM Humaniora volume XIV No. 1/2002.

Parera, Jos Daniel. 1991. Kajian Linguistik Umum, Historis Komparatif, dan Tipologi Struktural. Jakarta: Erlangga

Sudaryanto. 1993. Metode dan Aneka Teknik Analisis Bahasa. Yogyakarta: Duta Wacana University Press.

Sulaiman, Budiman. 1979. Bahasa Aceh. Jakarta: Pusat Pembinaan dan Pengembangan Bahasa, Depdikbud.

Verhaar, MM. 1987. Pengantar Linguistik. Yogyakarta: Gadjah Mada University Press.

Wurn, S.A dan B. Wilson. 1978. English Finderlist of Reconstruction in Austronesian Language. Canbera: The Australian National 